\title{
Empowerment of Rural Women through Self Help Groups
}

\author{
Sarah Kamala and Uma Jyothi*
}

\begin{abstract}
All India Coordinated Research Project on Home Science Department of Extension, Professor Jayashankar Telangana State Agricultural University, Hyderabad, Telangana, India
\end{abstract}

*Corresponding author

\begin{tabular}{|l|}
\hline Ke y w o r d s \\
Empowerment, Self \\
Help groups
\end{tabular}

\section{A B S T R A C T}

Empowerment is a process that helps people gain control over their own lives, communities and society. It is also a process, which enables one to realise his or her identity and power in all aspects of life. Empowerment occurs within, the factors- social, economic, political, personal, familial, and cultural at various spheres. In a period of time there are visible signs of empowerment of women due to the formation of Self Help Groups. Thousands of the poor and the marginalized population in India are building their lives, their families and their society through Self-help groups. Self-help Groups have been playing considerable role in exercise of infrastructure development, marketing and technology support, communication level of members, self confidence among members, family violence, interaction with outsiders, saving pattern of SHG members, change in the cumulative saving pattern of SHG members per month, involvement in politics, involvement in community activities, etc. The confidence level of women, who are illiterate, has gone up substantially. In terms of economics, women are now able to help their counterparts through agricultural season, family business, children educations, marriages, and many other house hold necessaries. The main aim of this paper is to examine the Role of Self-help Groups in Socio-psychological, economic and political development of women involved in SHGs. It analyses the present status of SHGs in terms of economic political and social empowerment succeeding involvement of women with the Self Help Groups. All the groups studied were working at least since five and more years and contributed a lot to its members. Being the members of self-help groups, majority of respondents reported an increase in self-confidence, self-esteem and participation in decision making, capacity building etc. i.e. improvement in psychological and social aspects along with the fruitful financial self-dependency.

\section{Introduction}

The empowerment of rural women is an imperative for development of economy of a country and also has significant role in creating a base for social transformation and change. In order to enhance the socioeconomic status of people in any country, it is a precondition to empower rural women by increasing and creating their participation to the best possible ways. If women are regarded as equal partners in development with men in rural areas, then only holistic and pleasant development of any nation would be achieved. Therefore, freedom to rural women is a prerequisite for economic development and 
upliftment of society and equal opportunities are to be given to rural women. The conceptual structure of Self Help Group (SHG) is a tool for empowerment. Self Help Groups play a significant role in empowering women through providing an excellent platform to improve the self- confidence, leadership, communication skills, decision making capacity, social recognition, standard of living etc. Empowerment can serve as a powerful instrument for women to achieve upward social and economic mobility and achieve power and status in the society. It is a source of mobility, equality and freedom, both at the individual and at the societal level. The Self-Help Group grows on the resources and management skills of its members and their increasing confidence to get involved in issues and programmes that require their involvement in the public and private spheres. SHG concept has helped to achieve economic and social empowerment. It has developed a sense of leadership, organizational skill, management of various activities of a business Manimekalai and Rajeswari (2001). Self-help groups are a prospective source to empower and encourage marginalized women to save and utilize savings to build self-reliance and confidence and provide greater access to and control over resources. Sudha Rani et al., (2002) in their study titled "SHGs, MicroCredit and Empowerment "observed that the participation in SHGs enhanced the empowerment of women in aspects like increase in self-confidence and decisionmaking power during the period of participation. The main vision for joining the SHG is not merely to get just credit but it is an empowerment process having with motivational attributes encouraging women to join the job. Saravana Kumar (2012) in his study stated that he principles of self-help and microcredit hold the key to economic and socio-cultural freedom for India's millions of poor, opening the gates of a hitherto untapped reservoir of human enterprise. Lalitha and
Nagarajan (2002) in their study highlighted the facts that SHGs were people's institutions and with their support, the women could march towards empowerment and that the groups could promote individual and group ventures of income generating activities. Establishment of Self-help groups under the movement of microfinance have brought remarkable transformation at the fundamental level by empowering women (Sahu and Singh, 2012).

\section{Materials and Methods}

A purposive sampling technique was used with combination of deliberate random sampling for the selection of total sample. The data were collected personally through interview technique with the help of prestructured questionnaire. The study was undertaken in 3 regions of Telangana State, representing 4 districts (Medak, Nalgonda, Karimnagar, and Ranga Reddy). A total of 1341 Office Bearers and 4858 Members' from 447 operating SHGs, covering 228 Mandals and 264 villages. From each of the four districts, SHG groups registered in 2008-09 were selected and secondary data from 2-3 SHGs from each village was collected tabulated and analyzed. This study measured in what way the Self-help Groups secured Socio-psychological, economic and political empowerment of women involved in SHGs. Self Help Groups create a higher degree of self-confidence and mutual thrust among women in rural areas and motivate them to be successful in their personal, family and social life (Azim, 2013). Thus, the present research is designed to study empowerment of rural women through self-help groups.

\section{Results and Discussion}

There are certain indicators through which we can measure the women empowerment like socio, economic and political empowerment. 
Measured the Status of Empowerment of SHG leaders/Office Bearers (447) and SHG members (894) and 417 Non-members on Five Point Continuum Scale developed for the study.

The Overall Empowerment status of both the office Bearers and members was high in all the aspects viz. Psycho-sociological empowerment, Economic Empowerment Legal and political Empowerment.

\section{Psychological empowerment}

Psychological power means the individual's sense of potency which is demonstrated in self-confident behavior and self-esteem.

\section{Social empowerment}

Social empower means access to certain bases of individual production such as financial resources, information, knowledge, skills and participation in social organization.

Table 1 reveals the Socio-Psychological empowerment of Office Bearers and members. Office Bearers (OB) empowerment is reported to be high with 88.0 percent and Members empowerment levels are reported to be almost equal to the OBs with 87 percentage.

This shows that they aim at realizing their identities, power and potentiality in all spheres of lives. The woman has increased access to economic resources, with more confidence and self-motivation, more strength, more recognition, more involvement in the family matters through participation. They got an opportunity to improve their hidden talents after joining the self-help groups.

\section{Economic empowerment}

Economic empowerment means access to income, assets, food, market and decision making power in the economic sphere.

Table 2 presents the adaptations that occurred in the economic empowerment of the members and office bearers during SHG period. It is found that there has been almost 90 per cent (88.1) increase in empowerment levels of SHG Office Bearers, who are now saving money in Bank and Post Offices and SHG, while the economic empowerment of members is also reported to be high with 87.0 percentage. It can be concluded that SHG is having a good impact on members and Office Bearers in their ability to save, saving pattern, economic Independence, Meet Emergency needs, Awareness about Bank interactions, Bargaining power, marketing etc.

Therefore, it can be concluded that after joining the SHGs members have improved their status in family, become helpful in family finance and sometimes helped others too.

Table.1 Distribution of SHG members according to socio-psychological empowerment

\begin{tabular}{|c|c|c|c|c|c|c|c|c|c|}
\hline & \multicolumn{3}{|c|}{$\begin{array}{c}\text { Percentage of office } \\
\text { bearers }\end{array}$} & \multicolumn{3}{|c|}{$\begin{array}{l}\text { Percentage of } \\
\text { members }\end{array}$} & \multicolumn{3}{|c|}{ Overall percentage } \\
\hline & $\begin{array}{l}\text { Low } \\
(1- \\
2.33)\end{array}$ & $\begin{array}{l}\text { Medium } \\
(\mathbf{2 . 3 4 -} \\
\text { 3.66) }\end{array}$ & $\begin{array}{l}\text { High } \\
(3.67 \\
-5.0)\end{array}$ & $\begin{array}{l}\text { Low } \\
(1- \\
\text { 2.33) }\end{array}$ & $\begin{array}{l}\text { Medium } \\
\text { (2.34- } \\
\text { 3.66) }\end{array}$ & $\begin{array}{l}\text { High } \\
(3.67 \\
-5.0)\end{array}$ & $\begin{array}{l}\text { Low } \\
(1- \\
2.33)\end{array}$ & $\begin{array}{l}\text { Medium } \\
\text { (2.34- } \\
\text { 3.66) }\end{array}$ & $\begin{array}{l}\text { High } \\
(3.67 \text { - } \\
5.0)\end{array}$ \\
\hline AP/Telangana & 1.7 & 10.3 & 88.0 & 3.24 & 9.85 & 86.91 & 2.47 & 10.07 & 87.46 \\
\hline
\end{tabular}


Table.2 Distribution of SHG members according to economic empowerment

\begin{tabular}{|c|c|c|c|c|c|c|c|c|c|}
\hline & \multicolumn{3}{|c|}{$\begin{array}{l}\text { Percentage of office } \\
\text { bearers }\end{array}$} & \multicolumn{3}{|c|}{ Percentage of member } & \multicolumn{3}{|c|}{ Overall percentage } \\
\hline & $\begin{array}{l}\text { Low } \\
(1- \\
2.33)\end{array}$ & $\begin{array}{l}\text { Medium } \\
\text { (2.34- } \\
\text { 3.66) }\end{array}$ & $\begin{array}{l}\text { High } \\
(3.67- \\
5.0)\end{array}$ & $\begin{array}{l}\text { Low } \\
(1- \\
2.33)\end{array}$ & $\begin{array}{l}\text { Medium } \\
\text { (2.34- } \\
\text { 3.66) }\end{array}$ & $\begin{array}{l}\text { High } \\
(3.67- \\
5.0)\end{array}$ & $\begin{array}{l}\text { Low } \\
(1- \\
2.33)\end{array}$ & $\begin{array}{l}\text { Medium } \\
(2.34- \\
\text { 3.66) }\end{array}$ & $\begin{array}{l}\text { High } \\
(3.67 \\
-5.0)\end{array}$ \\
\hline $\mathrm{P} / \mathrm{Te}$ & 0.3 & 11.6 & 88.1 & 4.1 & 8.9 & 87.0 & 3.24 & 9.31 & 87.45 \\
\hline
\end{tabular}

Table.3 Distribution of SHG members according legal/political empowerment

\begin{tabular}{|c|c|c|c|c|c|c|c|c|c|}
\hline & \multicolumn{3}{|c|}{$\begin{array}{l}\text { Percentage of office } \\
\text { bearers }\end{array}$} & \multicolumn{3}{|c|}{ Percentage of member } & \multicolumn{3}{|c|}{ Overall percentage } \\
\hline & $\begin{array}{l}\text { Low } \\
(1- \\
2.33)\end{array}$ & $\begin{array}{l}\text { Medium } \\
\text { 2.34- } \\
\text { 3.66) }\end{array}$ & $\begin{array}{l}\text { High } \\
(3.67 \\
-5.0)\end{array}$ & $\begin{array}{l}\text { Low } \\
(1- \\
2.33)\end{array}$ & $\begin{array}{l}\text { Medium } \\
\text { (2.34- } \\
\text { 3.66) }\end{array}$ & $\begin{array}{l}\text { High } \\
(3.67 \\
-5.0)\end{array}$ & $\begin{array}{l}\text { Low } \\
(1- \\
2.33)\end{array}$ & $\begin{array}{l}\text { Medium } \\
\text { (2.34- } \\
\text { 3.66) }\end{array}$ & $\begin{array}{l}\text { High } \\
(3.67 \\
\text { to 5.0) }\end{array}$ \\
\hline AP/Telangana & 2.2 & 21.3 & 76.5 & 8.63 & 17.31 & 74.06 & 5.42 & 19.30 & 75.28 \\
\hline
\end{tabular}

Table.4 Over all empowerment status

\begin{tabular}{|l|l|l|l|} 
& $\begin{array}{l}\text { Psychological } \\
\text { Empowerment }\end{array}$ & $\begin{array}{l}\text { Economic } \\
\text { Empowerment }\end{array}$ & $\begin{array}{l}\text { Legal/Political } \\
\text { Empowerment }\end{array}$ \\
\hline Office Bearers & $\mathbf{4 . 0 5}$ & $\mathbf{4 . 4 3}$ & $\mathbf{3 . 9 2}$ \\
\hline Members & $\mathbf{4 . 1 0}$ & $\mathbf{4 . 4 4}$ & $\mathbf{3 . 8 8}$ \\
\hline
\end{tabular}

\section{Political empowerment}

Political empower means the access of individual household members to the process by which decisions, particularly those that affect their own future are made.

Table 3 concludes the political empowerment of the Office Bearers (OB) and members. The empowerment level of the OBs is reported to be high with 76.5 percent whereas member's political empowerment level has reported to be little less with 74.06 percentage. This shows that Women members and leaders are supported to participate effectively in local decision making and to demand and realise rights, entitlements and access to quality public services. This fact has raised only with the association of women members with the Self Help Groups.
The table 4 demonstrates that overall empowerment of Office Bearers and Members. It is almost same in all the aspects of Empowerment i.e. Psychological, Economic and Political Empowerment of the members and Office Bearers with (4.05 vs. 4.10 socio -psycho), (4.43 vs. 4.44 Economic), (3.9 vs. 3.88 Political) mean scores. The women have come to know about the government schemes, rights and privileges, employment opportunities and the importance of professional jobs. Moreover, women have developed their leadership qualities like initiation, interaction with others, flexibility, adaptability, adjustability, increased their decision making capacity and developed their communication skills.

Gradual development has taken place in the lives of SHG women after joining the SHGs 
The outcomes of this study indicate that selfhelp groups have played a major and significant role in improving overall empowerment of rural women. It is concluded that self-help groups are having positive and progressive impact on empowerment of rural women. The present study has also indicated that even though the members have joined the SHGs for various reasons, all of them have one common goal, which is seeking a better standard of living via a better organization that works for their benefits. Hence, it could be concluded that the SHGs have proved that they could serve as an alternative instrument for the overall empowerment of the poor. The SHG can contribute to changes in economic conditions, social status, decision making and increases women in outdoor activities thus play a very important role in social change. SHG not only changes the outer form of a community or a society but also the social institutions as well as ideas of the people living in the society. In other words, it also applies to change the material aspects of life as well as in the ideas, values and attitudes of the people.

It is evident that women are empowered through Self Help Groups in various aspects of empowerment such as financial, economic, social and political by building them culturally, socially and economically better and it facilitates them to increase their incomes and savings through economic activities with technical supports through increasing awareness courage and enhanced participation in discussions at family, community and village level.

\section{References}

Lalitha, N., and B.S. Nagarajan, "Functioning of the SHGs in Selected Districts of Tamil Nadu" (eds.) Self-Help Groups in Rural development, New Delhi: Dominant Published and Distributors, 2002.

Manimekalai, M., and Rajeswari G. (2001). Nature and Performance of Informal Self Help Groups: A case from Tamil Nadu.Indian Journal of Agricultural Economics. 56(3), 453-54.

Sahu, Lopamudra and Singh, Suresh K., (2012), A Qualitative Study on Role of Self Help Group in Women Empowerment in Rural Pondicherry, India. National Journal of Community Medicine, 3(3), PP.473-479.

SaravanaKumar (2012) Self- Help Group in socio-economic transformation with special reference to Coimbatore. International Journal of Research in Commerce, Economic and Management. Vol.2(9), Pp:87-93.

Shakila Azim (2013), "Women Empowerment through Self Help Groups", Southern Economist, 52(6): pp.18-20.

Sudha Rani, K., D. Uma Devi and G. Surendra "SHGs, Micro-Credit and Empowerment", Social Welfare, February, 2002, pp. 20-22.

\section{How to cite this article:}

Sarah Kamala and Uma Jyothi. 2018. Empowerment of Rural Women through Self Help Groups. Int.J.Curr.Microbiol.App.Sci. 7(10): 3048-3052.

doi: https://doi.org/10.20546/ijcmas.2018.710.355 